Proceedings, Engineering Foundation Conference on Technological Solutions for Pollution Prevention in the Mining and Mineral Processing Industries.

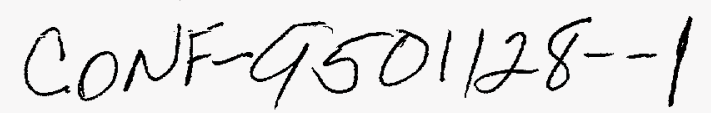

\title{
TREATMENT OF AQUEOUS STREAMS CONTAINING STRONG OXIDANTS USING BITUMINOUS COAL
}

\author{
Fiona M. Doyle and Donna L. Bodine \\ University of California at Berkeley, \\ Department of Materials Science and Mineral Engineering, \\ 551 Evans Hall\#1760, \\ Berkeley, CA 94720-1760, USA.
}

\begin{abstract}
Certain oxidizing contaminants, notably $\mathrm{Cr}(\mathrm{VI})$ and $\mathrm{Mn}(\mathrm{VII})$, are attenuated by reduction and sorption on organic matter in soils. Coals have some chemical similarity with this organic matter, and might be used on an industrial scale to treat effluents. We have studied the ability of acidic $\mathrm{KMnO}_{4}$ to oxidize Upper Freeport, bituminous coal with concurrent sorption of the resulting $M n(I V)$ and $M n(I I)$. The oxidizing ability of $\mathrm{Cr}(\mathrm{VI})$ was briefly investigated. The ability of the oxidized coal to sorb $\mathrm{Cu}^{2+}$ and $\mathrm{Cd}^{2+}$ was then studied, and compared with coal oxidized by hydrogen peroxide. The effect of oxidation treatment, metal ion concentration, and solution $\mathrm{pH}$ on metal uptake kinetics and coal loading was investigated. Potential applications for treating effluents containing oxidizing ions are discussed.
\end{abstract}

\section{INTRODUCTION}

The discharge of certain inorganic oxidants is strictly regulated because of the impact of oxidizing species on living organisms, and the inherent toxicity or carcinogenicity of some species, such as $\mathrm{Cr}(\mathrm{VI})$. Although many of these oxidants are known to be attenuated by reduction and sorption on organic matter in soils, this can produce contaminated soils and groundwater. Effluents and wastes containing problematic oxidants must be treated with reducing agents that can concentrate contaminants into treatable or disposable form. Unless they can be regenerated, reducing agents should be inexpensive and readily available. Since oxidizing contaminants are often associated with other species that are regulated because of their inherent toxicity, notably metals, it would be advantageous if these could be removed from solution at the same time.

Activated carbon appears to be effective for removing $\mathrm{Cr}(\mathrm{VI})$ from solution below $\mathrm{pH}$ $6(1)$. Bituminous coal was of interest as a potential reducing agent for several reasons. It is inexpensive and readily available. Coal has some chemical similarity with the organic material in soils that attenuates reducing agents; the more reduced state of coal makes it a very attractive reductant. Smith and Mapstone, for example, reported reduction of alkaline $\mathrm{KMnO}_{4}$ by an Australian coal with precipitation of 
$\mathrm{MnO}_{2}(2)$. Precipitates such as $\mathrm{Mn}$ are capable of sorbing soluble metal species, either reduction products of the oxidants, or other contaminants, thereby removing them from solution. Precipitates would be expected to nucleate on the coal, thereby facilitating subsequent solid/liquid separations. Furthermore, coal forms carboxylic and phenolic surface groups on oxidation; these can also complex and immobilize toxic metal ions. As discussed later, metal-laden coal might be treated by elution with acid, or by combustion and appropriate management of the resulting ash.

We have examined the ability of a bituminous coal to reduce $\mathrm{KMnO}_{4}$ to $\mathrm{Mn}$ (IV) and $\mathrm{Mn}$ (II), which are adsorbed onto the coal surface, probably forming a manganese oxide surface layer. Because the oxidized coal and the manganese oxide might sorb other cations, the ability of coal samples oxidized by $\mathrm{KMnO}_{4}$ to remove $\mathrm{Cu}^{2+}$ and $\mathrm{Cd}^{2+}$ (selected as model contaminants) from solution was studied. This behavior was compared with that of coal samples oxidized by $\mathrm{H}_{2} \mathrm{O}_{2}$. In addition, preliminary experiments on the reduction of $\mathrm{Cr}(\mathrm{VI})$ by the same coal are reported.

\section{EXPERIMENTAL METHODS}

Upper Freeport MV bituminous coal was obtained from the Troutville \#2 Mine, Clearfield County, Pennsylvania and stored under argon after mining to prevent oxidation. The coal contained $17.59 \%$ ash, $27.05 \%$ volatile matter, $55.35 \%$ fixed carbon, $1.50 \%$ moisture, $0.68 \%$ phenolic oxygen and $1.01 \%$ carboxylic oxygen, on an as-received basis(3). The coal was ground in a ball mill, sieved, and the +250 200 mesh ( 63 to $75 \mu \mathrm{m}$ ) size fraction was stored under argon for use in this work.

The ability of the coal to remove $\mathrm{Mn}(\mathrm{VII})$ and $\mathrm{Cr}(\mathrm{VI})$ from aqueous solution through a combination of reduction and adsorption was investigated. Coal samples were stirred for 4 hours with $100 \mathrm{ml}$ of $\mathrm{pH} 3,8.42 \times 10^{-3} \mathrm{M} \mathrm{KMnO}_{4}$ solution at $25^{\circ} \mathrm{C}$. $10 \mathrm{~g}$ samples of coal were stirred for 4 hours with $100 \mathrm{ml}$ of dilute $\mathrm{K}_{2} \mathrm{CrO}_{4}$ solution at $\mathrm{pH}$ 2.5 and 5.5. For all tests, suspension samples were filtered under vacuum, and the filtrate was analyzed using a Perkin Elmer 3110 atomic absorption spectrometer.

Metal uptake experiments used either raw coal, coal pretreated by $8.42 \times 10^{-3} \mathrm{M}$ $\mathrm{KMnO}_{4}$ solution, using $100 \mathrm{~g}$ of coal/liter, or coal pretreated by $\mathrm{H}_{2} \mathrm{O}_{2}$, which creates functional groups but no solid oxide, and was studied for comparison. $500 \mathrm{ml}$ of $30 \%$ hydrogen peroxide ( $\mathrm{pH}=4.9$ ) was used to pretreat $20 \mathrm{~g}$ of coal for about 2.5 hours, until there was no further effervescence, using an ice bath to prevent thermal decomposition of the $\mathrm{H}_{2} \mathrm{O}_{2}$. $15 \mathrm{~g}$ samples of raw or pretreated coal were shaken with $150 \mathrm{ml}$ copper or cadmium sulfate solutions, prepared from $0.05 \mathrm{M}$ stock solutions with no pH adjustment, at $25^{\circ} \mathrm{C}$, The partition of metals between coal samples pretreated by $\mathrm{KMnO}_{4}$ and $\mathrm{Cu}$ or $\mathrm{Cd}$ sulfate solutions was studied from $\mathrm{pH}$ 1 to 13. For each experiment, 1 gram of coal was shaken with $10 \mathrm{ml}$ of metal solution at $25^{\circ} \mathrm{C}$ for 2 hours, and the suspension was analyzed as described above.

\section{RESULTS AND DISCUSSION}

\section{Removal of Oxidants by Coal}

Table 1 shows the effect of the coal:solution ratio on the final Mn concentration after four hours of contact with a solution initially containing $8.4 \times 10^{-3} \mathrm{M} \mathrm{Mn}$ (VII). There is a minimum in the final concentration of $\mathrm{Mn}$ as a function of weight of coal added. The solution potential using $10 \mathrm{~g}$ of coal, which gave a final Mn concentration below 
Table 1: Effect of coal concentration on removal of Mn(VII) by Upper Freeport coal from $100 \mathrm{ml}$ of $462 \mathrm{ppm} \mathrm{Mn}(\mathrm{VII})\left(8.4 \times 10^{-3} \mathrm{M}\right), \mathrm{pH} 3$ solution in 4 hours

\begin{tabular}{|c|c|c|c|c|c|c|c|}
\hline Coal in $100 \mathrm{ml} \mathrm{KMnO}_{4}$ solution $(\mathrm{g})$ & 1 & 3 & 5 & 10 & 12.5 & 15 & 20 \\
\hline Final Mn Concentratiōn (ppm) & 347 & $\overline{168}$ & ND & $\overline{N D}$ & 12 & 5 & 18 \\
\hline
\end{tabular}

$\mathrm{ND}=$ not detected

Table 2: Effect of initial chromate concentration, $[\mathrm{Cr}(\mathrm{VI})] \mathrm{o}$, and $\mathrm{pH}$ on total $\mathrm{Cr}(\mathrm{III})$ and $\mathrm{Cr}(\mathrm{VI})$ concentration, [Crltot, after 4 hours treatment with Upper Freeport coal

\begin{tabular}{|c|c|c|c|}
\hline$[\mathrm{Cr}(\mathrm{VI})]_{0}(\mathrm{ppm})$ & $\mathrm{pH}_{\mathrm{o}}$ & {$[\mathrm{Cr}]_{\text {tot }}(\mathrm{ppm})$} & Final color \\
\hline 1200 & 2.5 & 800 & yellow \\
\hline 1100 & 5.5 & 800 & yellow \\
\hline 18 & 2.5 & 17 & colorless \\
\hline 13 & 5.5 & 7 & colorless \\
\hline
\end{tabular}

detection, was $1.22 \mathrm{~V}$ (SHE). Comparing this potential with the Eh-pH diagrams for the $\mathrm{Mn}-\mathrm{H}_{2} \mathrm{O}$ system(4) suggests that at moderate coal concentrations, Mn(VII) is reduced to insoluble $\mathrm{MnO}_{2}$, whereas at higher coal concentrations, soluble $\mathrm{Mn}^{2+}$ is the final reduction product. X-ray diffraction of coal oxidized by $\mathrm{KMnO}_{4}$ did not detect a crystalline phase, and no surface oxide layers were visible by SEM. Therefore, any manganese oxide that formed on the coal surface must be amorphous or microcrystalline.

Table 2 presents the results of preliminary studies on the removal of $\mathrm{Cr}$ using coal. Individual species were not analyzed, but the color after 4 hours, in conjunction with the Eh-pH diagram for the $\mathrm{Cr}-\mathrm{H}_{2} \mathrm{O}$ system(3), suggests that the very dilute samples were completely reduced to $\mathrm{CrOH}^{2+}$. Reduction consumes hydrogen, as demonstrated by the following "model" reaction, in which for simplicity, $\mathrm{Cr}(\mathrm{VI})$ is considered to oxidize elemental carbon to $\mathrm{CO}_{2}$ :

$$
4 \mathrm{HCrO}_{4}^{-}+3 \mathrm{C}+12 \mathrm{H}^{+}=4 \mathrm{CrOH}^{2+}+6 \mathrm{H}_{2} \mathrm{O}+3 \mathrm{CO}_{2}
$$

The resulting increase in $\mathrm{pH}$ would favor precipitation of some $\mathrm{Cr}_{2} \mathrm{O}_{3}$. The yellow color of the more concentrated solution indicates residual $\mathrm{Cr}(\mathrm{VI})$ using $10 \mathrm{~g}$ of coal to $100 \mathrm{ml}$ of solution. However appreciable $\mathrm{Cr}$ was removed from solution, probably due to partial reduction of $\mathrm{Cr}(\mathrm{VI})$, and precipitation of $\mathrm{Cr}_{2} \mathrm{O}_{3}$. Although much more work is needed to quantify the ability of coal to reduce $\mathrm{Cr}(\mathrm{VI})$, the preliminary results here demonstrate some capability that could be optimized with $\mathrm{pH}$ and Eh control.

\section{Uptake of Cu and Cd by Oxidlzed Coal}

Raw coal removed little $\mathrm{Cu}$ or $\mathrm{Cd}$ from solution. Figure 1 shows the effects of pretreatment with hydrogen peroxide and $\mathrm{Mn}(\mathrm{VII})$ on the removal of $\mathrm{Cd}$ from a 4.43 $\times 10^{-3} \mathrm{M}$ (498 ppm), $\mathrm{pH}=6$ solution. Cd was removed rapidly initially, followed by little additional change in Cd solution concentration. Coal oxidized by $\mathrm{KMnO}_{4}$ was more effective than coal oxidized by $\mathrm{H}_{2} \mathrm{O}_{2}$ in sorbing $\mathrm{Cd}$. This suggests a significant difference in the surface conditions after the two different treatments. This could reflect the fact that the redox potential was about $1.22 \mathrm{~V}$ (SHE) during pretreatment of coal with $\mathrm{KMnO}_{4}$, and only about $0.76 \mathrm{~V}$ (SHE) during pretreatment with $\mathrm{H}_{2} \mathrm{O}_{2}$, and hence the coal would be expected to be more extensively oxidized after treatment with $\mathrm{KMnO}_{4}$. However the differences could also be due to the formation of insoluble manganese oxide on the coal surface after treatment with 
$\mathrm{KMnO}_{4}$. The removal of $\mathrm{Cu}$ from $4.8 \times 10^{-3} \mathrm{M}$ solution was very similar. Because metal uptake was rapid, the kinetics were studied further. Figure 2 shows the $\mathrm{Cu}$ concentration in a solution initially containing $4.8 \times 10^{-3} \mathrm{M} \mathrm{CuSO}_{4}$, as a function of time in contact with coal pretreated with $\mathrm{KMnO}_{4}$. All significant $\mathrm{Cu}$ uptake occurred in the first ten minutes (shorter periods could not be studied reliably, because of filtration limitations). This strongly suggests that metals could be sorbed during treatment of a waste containing both permanganate and other metals with raw coal.

Figure 3 shows the uptake of $\mathrm{Cu}$ from a more dilute system $\left(4.6 \times 10^{-4} \mathrm{M}, \mathrm{pH}=5.3\right)$ by oxidized coal. In this figure the parentheses (1) and (2), and corresponding closed and open symbols, designate different experiments, with starting times staggered to facilitate sampling. Coal pretreated by $\mathrm{KMnO}_{4}$ was very effective in removing $\mathrm{Cu}$ from the more dilute system, eventually achieving $2.3 \mathrm{ppm}$ residual $\mathrm{Cu}$ ( $8 \%$ of the original). Coal oxidized by $\mathrm{H}_{2} \mathrm{O}_{2}$ was ineffective.

Mn ions were released during sorption of metals by coal pre-oxidized by $\mathrm{KMnO}_{4}$. Figure 4 shows the magnitude of this change in $\mathrm{Cd}$ and $\mathrm{Mn}$ concentration with time. The Cd in solution decreased somewhat in the first two hours after contact with oxidized coal, after which very little further sorption occurred. Some Mn was released into solution during Cd uptake, but although there is some ion exchange between $\mathrm{Mn}$ and $\mathrm{Cd}$, the two changes are not related by an exact stoichiometric relationship. There was also no stoichiometric relationship between uptake of $\mathrm{Cu}$ and concurrent release of $\mathrm{Mn}$. This suggests that metal ions are adsorbed by exchange with both $\mathrm{Mn}$ ions in the surface oxide and hydrogen ions in the functional groups on the oxidized coal surface.

\section{Metal Uptake at Different pH}

$\mathrm{Cu}$ and $\mathrm{Cd}$ uptake on coal pretreated by $\mathrm{KMnO}_{4}$ was studied as a function of $\mathrm{pH}$ to identify whether bulk precipitation of metal hydroxides started competing with sorption, and assess whether metal uptake depends primarily on the coal surface functional groups generated by the different oxidation treatments, or is predominantly influenced by hydrolysis of the cations in solution. Figure 5 shows the change in concentration of $\mathrm{Cu}$ and $\mathrm{Mn}$ ions in solution, as a function of initial solution $\mathrm{pH}$. Figure 6 presents the change in concentration of $\mathrm{Cd}$ and $\mathrm{Mn}$ ions. Very little $\mathrm{Cu}$ or $\mathrm{Cd}$ was removed at very low $\mathrm{pH}$. The metal removals increased with increasing $\mathrm{pH}$, steadily for $\mathrm{Cu}$, and up to a plateau for $\mathrm{Cd}$. Each system then reached a threshold where the metal was almost completely removed from solution, between $\mathrm{pH} 5$ and 6 for $\mathrm{Cu}$, and between $\mathrm{pH} 8$ and 9 for $\mathrm{Cd}$. These thresholds coincided with the pH's where bulk metal hydroxides precipitated during testing.

Figures 5 and 6 show that the amount of Mn released into solution decreased with increasing initial $\mathrm{pH}$, and is not related to the uptake of $\mathrm{Cu}$ or $\mathrm{Cd}$. Thus it is proposed that any manganese oxide present on the surface of coal pretreated by $\mathrm{KMnO}_{4}$ undergoes simple, $\mathrm{pH}$ dependent reductive dissolution:

$$
\mathrm{MnO}_{\mathrm{x}}+2 \mathrm{xH}+2(\mathrm{x}-1) \mathrm{e}=\mathrm{Mn}^{2+}+\mathrm{xH}_{2} \mathrm{O}
$$

Under some conditions, $\mathrm{Cu}$ and $\mathrm{Cd}$ might sorb by ion exchange onto the $\mathrm{MnO}_{2}$, but they can also be taken up by functional groups on the coal surface, or themselves form surface precipitates. The predominant mechanism is clearly $\mathrm{pH}$ dependent. 


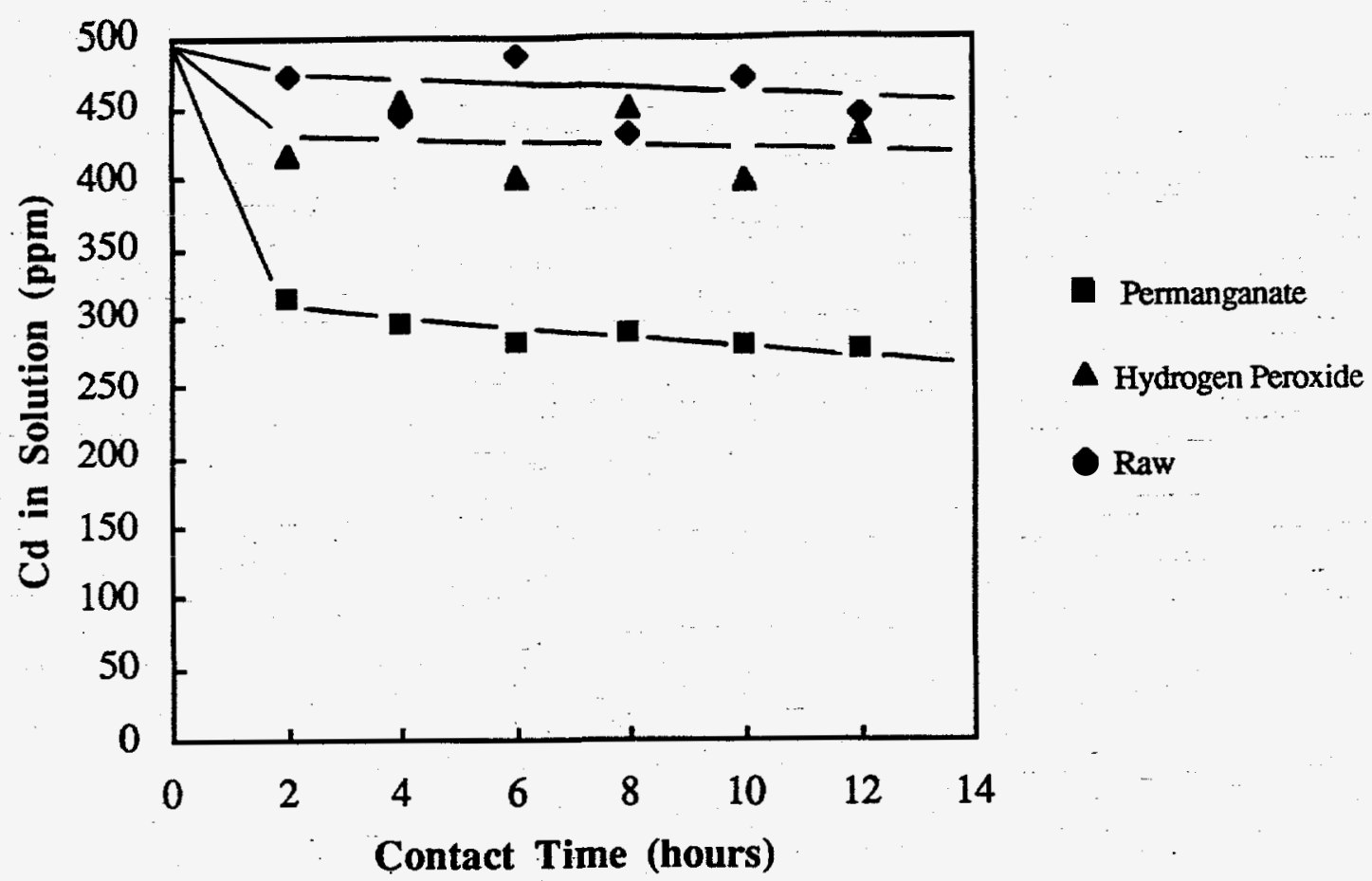

Figure 1: Effect of Upper Freeport coal oxidation treatment on removal of $\mathrm{Cd}$ from $4.43 \times 10^{-3} \mathrm{M} \mathrm{CdSO}_{4}$ solution (498 ppm Cd), initial pH 6.0.

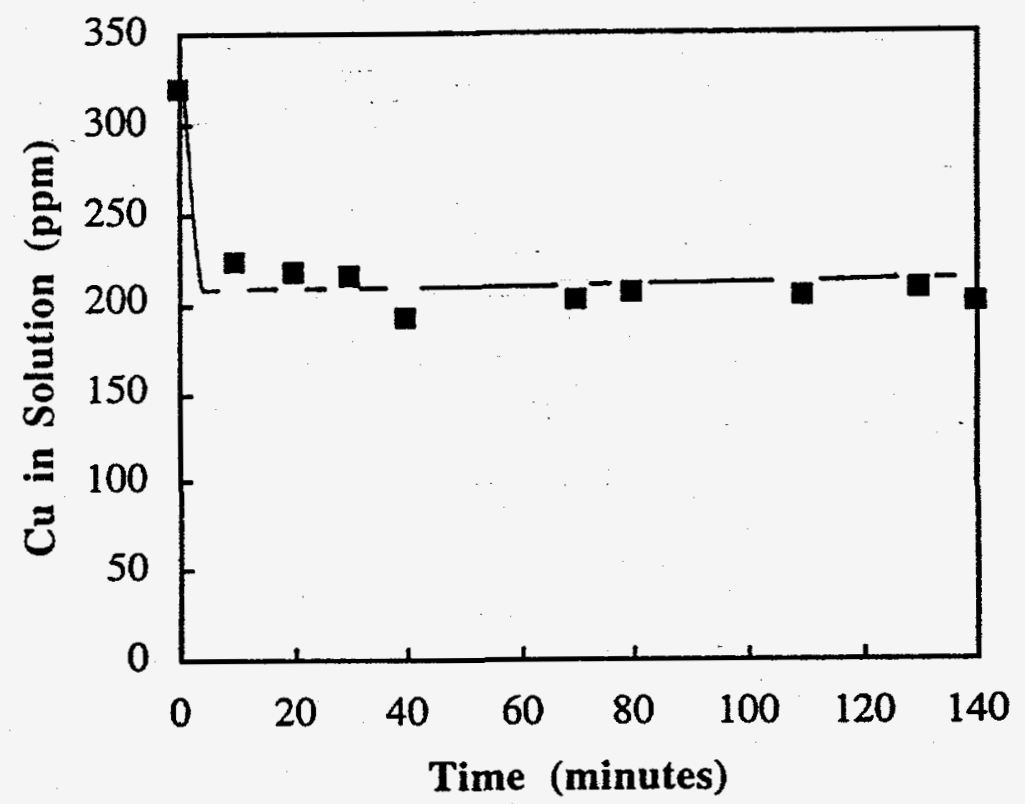

Figure 2: Removal of $\mathrm{Cu}$ from $4.8 \times 10^{-3} \mathrm{M} \mathrm{CuSO}_{4}$ solution (305 ppm Cu), initial pH 3.1 by coal pretreated with $\mathrm{KMnO}_{4}$. 


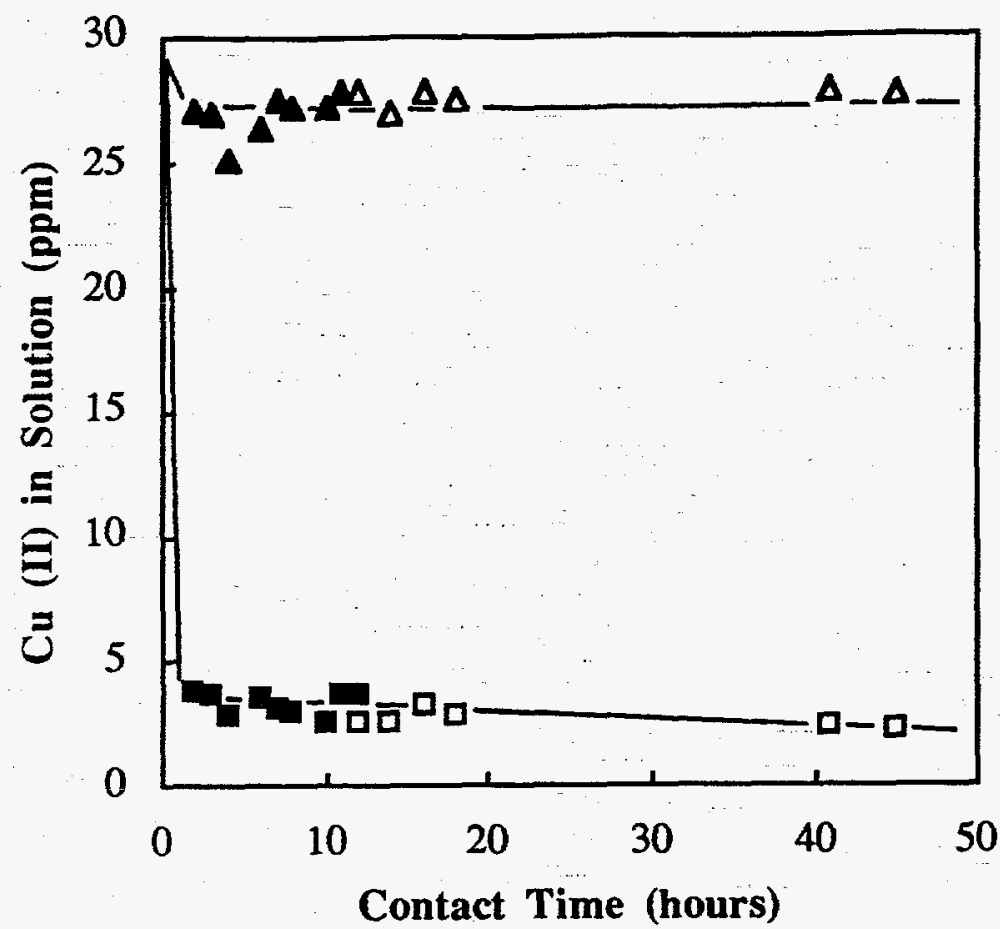

- Permanganate (1)

D Permanganate (2)

Aydrogen Peroxide (1)

$\Delta$ Hydrogen Peroxide (2)

Figure 3: Effect of coal oxidation treatment on removal of $\mathrm{Cu}$ from $4.6 \times 10^{-4} \mathrm{M}$ $\mathrm{CuSO}_{4}$ (29 ppm Cu), initial pH 5.3.

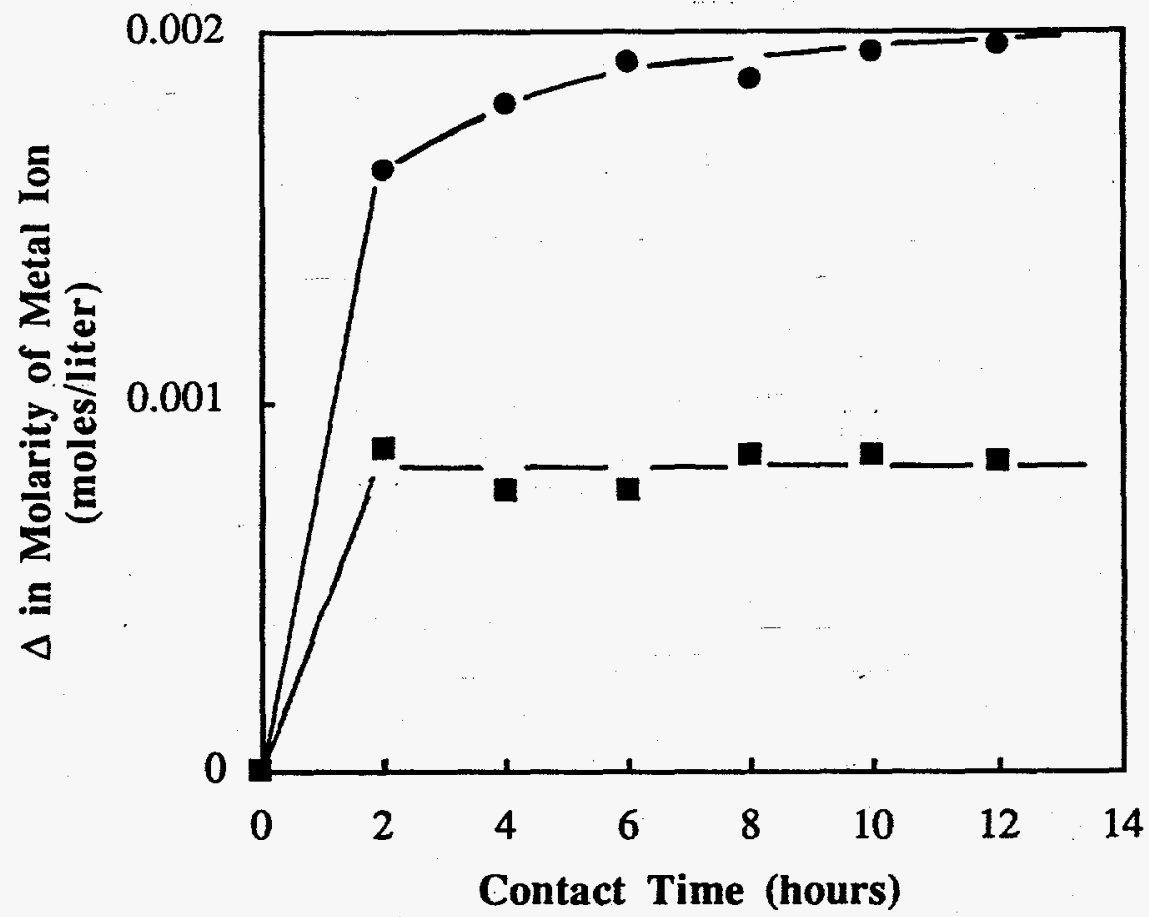

Cadmium

Manganese

Figure 4: Magnitude of change in concentration of $\mathrm{Cd}$ and $\mathrm{Mn}$ ions during contact of $\mathrm{KMnO}_{4}$ oxidized Upper Freeport coal with $4.43 \times 10^{-3} \mathrm{M}(498 \mathrm{ppm})$ Cd solution. (Cd concentrations decreased, Mn concentrations increased.) 


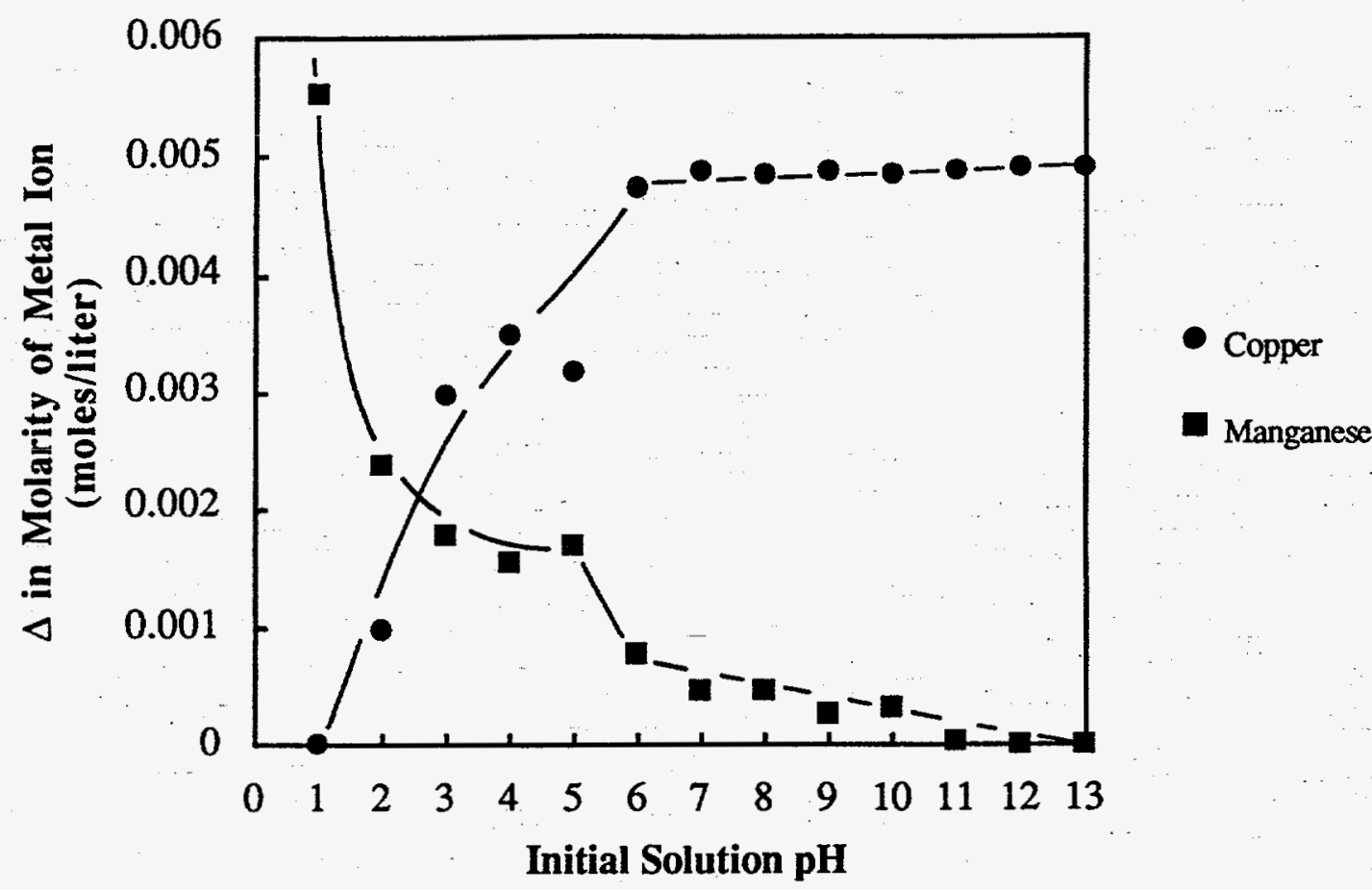

Figure 5: Magnitude of change in concentration of $\mathrm{Cu}$ and $\mathrm{Mn}$ ions during contact of $\mathrm{KMnO}_{4}$ oxidized Upper Freeport coal with $4.9 \times 10^{-3} \mathrm{M}(312 \mathrm{ppm}) \mathrm{Cu}$ solution, as a function of initial solution $\mathrm{pH}$.

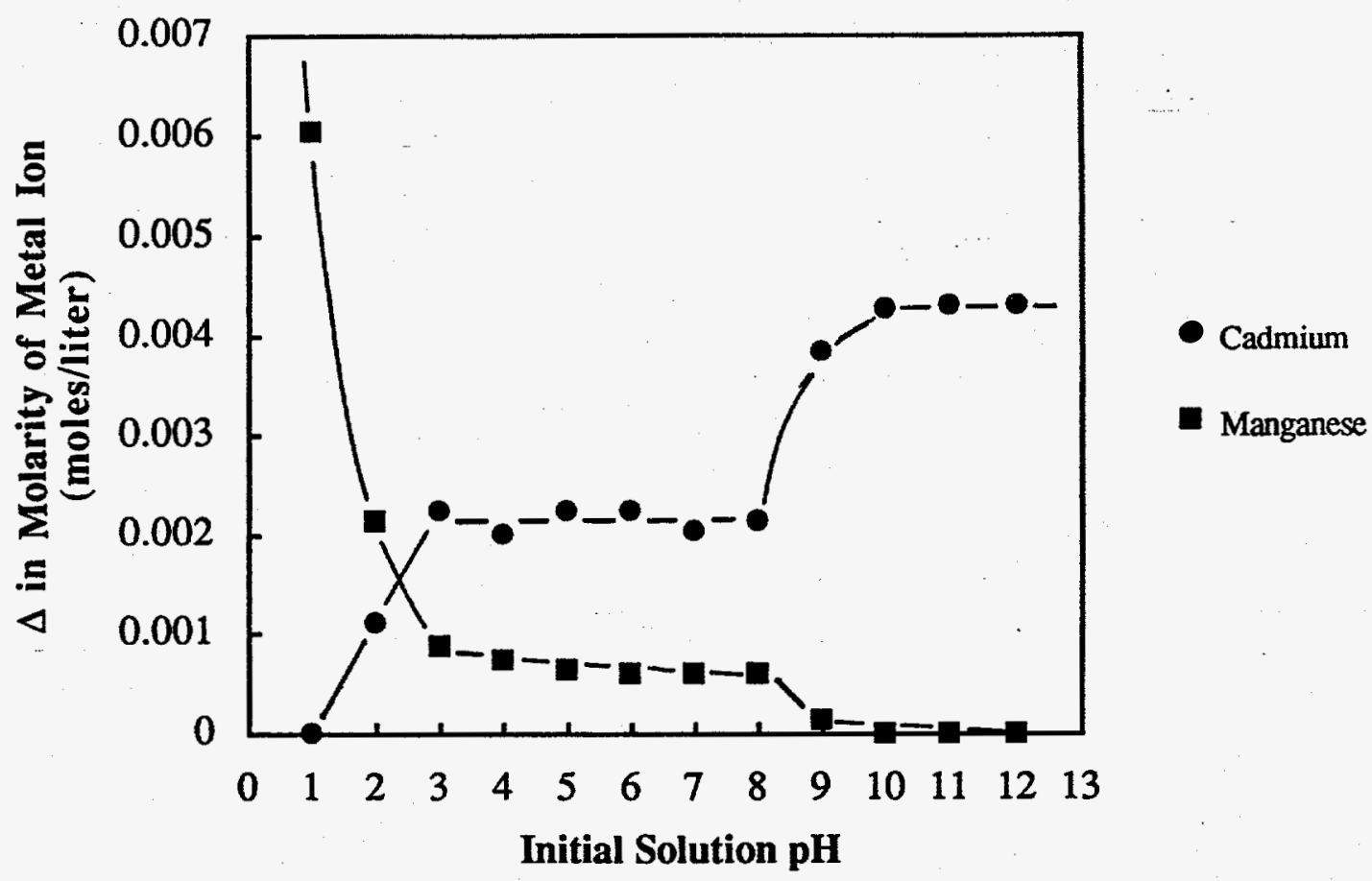

Figure 6: Magnitude of change in concentration of $\mathrm{Cd}$ and $\mathrm{Mn}$ ions during contact of $\mathrm{KMnO}_{4}$ oxidized Upper Freeport coal with $4.3 \times 10^{-3} \mathrm{M}(486 \mathrm{ppm})$ Cd solution, as a function of initial solution $\mathrm{pH}$. 


\section{Potential Commerclal Application for Treating Effluents}

Coal is able to reduce oxidizing contaminants present in aqueous solutions. The ability to sorb the resulting reduced species depends on the specific chemistry of the contaminants. After oxidation, the coal is able to remove toxic metals cations from dilute solution, with an efficacy that appears consistent with both the hydrolysis order of the cations, and their affinity for carboxylate groups, as observed in solvent extraction $(5,6)$. It is not possible to predict the behavior of other contaminants, but the results here are sufficiently encouraging to warrant studying the ability of oxidized coal to adsorb other ionic species. Although coal could not remove all cations in single batch contacts, metal uptake appears to result from ion exchange with functional groups, and sorption on $\mathrm{MnO}_{2}$, if this is present, and the behavior is influenced by metal ion concentration and solution $\mathrm{pH}$ in a way that is consistent with an equilibrium being established. This suggests that significant removal of contaminants could be achieved by counter-current contacting, using columns or a series of continuously stirred batch reactors with counter-current decantation.

Two detoxification methods might be appropriate for metal-laden coal; it could be amenable to elution with acid, as is used for ion-exchange resins. Alternatively, the coal could be burned, causing the contaminants to report to the ash phase. If the ash released toxic metals easily, it could be treated by leaching, to recover a marketable metal product, and facilitate disposal. Alternatively, the toxic metals might report to inert crystalline or glassy phases in the ash, which could then be discarded without further treatment. The latter behavior is likely to be favored by higher combustion temperatures. Whether coal could be detoxified in existing combustion devices, such as power stations or cement kilns, or would require a dedicated facility, would depend on its composition, and many site-specific factors.

\section{CONCLUSIONS}

When $\mathrm{KMnO}_{4}$ was reduced by coal, most of the $\mathrm{Mn}$ (VII) was removed from solution through reduction and adsorption of $\mathrm{MnO}_{2}$. When an excess of coal induced a very low solution potential, $\mathrm{Mn}^{2+}$ formed, and was less strongly sorbed. Coal pretreated by $\mathrm{KMnO}_{4}$ could also take up $\mathrm{Cu}$ and $\mathrm{Cd}$ ions, with $\mathrm{pH}$ dependent release of $\mathrm{Mn}$ ions into solution, apparently by a combination of ion exchange and acid dissolution. Realistic water quality goals are likely to be achievable using counter-current contacting in commercial reactors. Coal was less able to reduce $\mathrm{Cr}(\mathrm{VI})$ and sorb the reduced species, presumably because of the lower potential needed.

\section{ACKNOWLEDGEMENTS}

This work has been sponsored by the United States Department of Energy, Pittsburgh Energy Technology Center under Grant Number DE-FG22-90PC90287

\section{REFERENCES}

1. Huang and Wu, Water Research Vol. 11, 673-679, 1977.

2. J.W. Smith and G.E. Mapstone, Fuel 35 (2) (1957), $191-204$.

3. M.N. Herrera, Ph.D. Dissertation, University of Califomia at Berkeley, Dec. 1994.

4. D.G. Brookins, Eh-pH Diagrams for Geochemistry, Springer-Verlag, 1988.

5. E.L.T.M. Spitzer, J. Radder and H.M. Muys, Trans. I.M.M., C75 (1966) 265-266.

6. D.S. Flett, Nature, 200 (1963) $465-466$. 


\section{DISCLAIMER}

This report was prepared as an account of work sponsored by an agency of the United States Government. Neither the United States Government nor any agency thereof, nor any of their employees, makes any warranty, express or implied, or assumes any legal liability or responsibility for the accuracy, completeness, or usefulness of any information, apparatus, product, or process disclosed, or represents that its use would not infringe privately owned rights. Reference herein to any specific commercial product, process, or service by trade name, trademark, manufacturer, or otherwise does not necessarily constitute or imply its endorsement, recommendation, or favoring by the United States Government or any agency thereof. The views and opinions of authors expressed herein do not necessarily state or reflect those of the United States Government or any agency thereof. 